\title{
A Longitudinal Metric Analysis of Course-subjects to Reveal the Evolution of a Discipline: Changes in the Teaching Frequency and Ratio of Courses in Law Schools in the United States over 80 years
}

\author{
Peter A. Hook* \\ School of Library and Information Science, Wayne State University, Detroit, MI 48202, USA
}

\begin{abstract}
This article is a longitudinal, metric analysis of law school course-subjects in the United States. Its data source is the lists of "teachers by subject" contained in the annual directories of the American Association of Law Schools for a total of 57,915 data points. The number of faculty teaching the various course-subjects is compared for three time periods: (1) 1931-1932, (2) 1972-1973, and (3) 2010-2011. The course-subjects are a controlled vocabulary. In addition, the mergence and divergence of course-subjects are noted based on the timing of changes, "includes" statements, and "see also" references. This allows meaningful comparisons across time to reveal which coursesubjects and groups of related course-subjects are rising and falling in importance in the legal academy in the United States. Topics such as International Law, Constitutional Law, and Legal Research and Writing have gained the most in terms of the percentage number of teachers teaching these topics. Topics such as Estate Planning, Commercial Law, and Business Associations have lost the most in terms of the percentage number of teachers teaching these topics. In addition, the course-subjects with the highest and lowest average of the length of time they have been taught are reported for each period.
\end{abstract}

Keywords: Course-Subjects, Data mining, Informetrics, Law, Metrics, Topic analysis.

\section{INTRODUCTION}

The American Association of Law Schools (AALS) ${ }^{[1]}$ is the main learned society for legal academics in the United States. At present, there are close to 200 law schools accredited by the American Bar Association (ABA) and most are members of the AALS [Table 1]. Since 19311932, the AALS has published an annual directory of its membership that includes a "List of Law Teachers by

*Address for correspondence:

E-mail: peter.hook@wayne.edu.

\begin{tabular}{|c|c|}
\hline \multicolumn{2}{|c|}{ Access this article online } \\
\hline Official Publication of & \\
\hline & $\begin{array}{l}\text { Website: } \\
\text { www.jscires.org }\end{array}$ \\
\hline PhCOG & $\begin{array}{l}\text { DOI: } \\
\text { 10.5530/jscires.5.1.4 }\end{array}$ \\
\hline
\end{tabular}

Subject." $[2,3]$ The course-subjects included in these lists are a controlled vocabulary. Faculty members teaching courses with varying titles and descriptions are listed in the most relevant course-subject category. Together, the course-subjects comprise the unofficial "canon" of topics taught in law schools in the United States. In addition, faculty members teaching each course-subject are binned as to how long they have been teaching that particular course-subject (1) 1-5 years, (2) 6-10 years, and (3) over 10 years. This rich infrastructure allows for insightful

This is an open access article distributed under the terms of the Creative Commons Attribution-NonCommercial-ShareAlike 3.0 License, which allows others to remix, tweak, and build upon the work non-commercially, as long as the author is credited and the new creations are licensed under the identical terms.

How to cite this article: Hook PA. A longitudinal metric analysis of coursesubjects to reveal the evolution of a discipline: Changes in the teaching frequency and ratio of courses in law schools in the United States over 80 years. J Scientometric Res. 2016;5(1):13-24. 
Table 1: Law schools by year and category

\begin{tabular}{|c|c|c|c|c|c|}
\hline \multirow[t]{2}{*}{ Date } & \multicolumn{4}{|c|}{$\begin{array}{l}\text { Number of schools } \\
\text { included in the AALS } \\
\text { directories (with lists of } \\
\text { law teachers by school) }\end{array}$} & \multirow{2}{*}{$\begin{array}{l}\text { Number of ABA- } \\
\text { accredited schools } \\
\text { (still in existence } \\
\text { in } 2010 \text { ) that were } \\
\text { accredited at that } \\
\text { time (source: ABA } \\
\text { and LSAC, 2010) }{ }^{[13]}\end{array}$} \\
\hline & Total & US & Canada & Other & \\
\hline $\begin{array}{l}1923-1924 \text { (first } \\
\text { year of ABA } \\
\text { accreditation) }\end{array}$ & 58 & 56 & 1 & 1 & 40 \\
\hline $\begin{array}{l}1930-1931 \\
(A A L S, 1930)^{[5]}\end{array}$ & 68 & 66 & 1 & 1 & 73 \\
\hline $\begin{array}{l}\text { 1940-1941 } \\
(\text { AALS, 1940) })^{[6]}\end{array}$ & 91 & 90 & 0 & 1 & 101 \\
\hline $\begin{array}{l}1950-1951 \\
(A A L S, 1950)^{[7]}\end{array}$ & 107 & 105 & 0 & 2 & 117 \\
\hline $\begin{array}{l}\text { 1960-1961 } \\
(\text { AALS, 1960) })^{[8]}\end{array}$ & 131 & 130 & 0 & 1 & 130 \\
\hline $\begin{array}{l}1970-1971 \\
\left(\text { AALS, 1970) }{ }^{[9]}\right.\end{array}$ & 147 & 145 & 0 & 2 & 147 \\
\hline $\begin{array}{l}\text { 1980-1981 } \\
\text { (AALS, 1981)[10] }^{[10}\end{array}$ & 192 & 168 & 21 & 3 & 168 \\
\hline $\begin{array}{l}1989-1990 \\
(A A L S, 1989)^{[11]}\end{array}$ & 197 & 172 & 22 & 3 & 173 \\
\hline $\begin{array}{l}\text { 2010-2011 } \\
(\text { AALS, 2013) })^{[12]}\end{array}$ & 198 & 196 & 0 & 2 & 198 \\
\hline
\end{tabular}

AALS: American Association of Law Schools, ABA: American Bar Association, LSAC: Law School Admission Council.

metric analysis that includes the rise and fall of various course-subjects in terms of their overall percentage of the course-subjects being taught, average length of time the course-subjects have been taught by their faculty members, mergence and divergence of course-subjects, and meaningful comparisons across 80 years. In another paper, the author has used a similar dataset involving course-subject co-occurrence (CSCO) (when two coursesubjects are taught in the same academic year by the same teacher) to visualize and map the domain of law in the United States. ${ }^{[4]}$

\section{Related Work}

There has been a long history of doing metric analysis to gain insights into a domain. ${ }^{[14,15]}$ Most similar to this work, there have also been studies that analyze course catalogs for trends in academic disciplines such as change and development in the overall subject matter, first appearances of particular subjects, and the end of particular subjects. For instance, Perlman and McCann examined 400 college catalogs to do an analysis of course offerings in undergraduate psychology curriculums. ${ }^{[16]}$ Comparing their contemporary findings with earlier studies allowed the authors to identify new pedagogical approaches, clinical advances, other trends, and the changes in the discipline's "constituencies" over time (e.g., the balance between such things as vocational/nonvocational or applied/nonapplied courses). Similarly, as part of his survey of doctoral education in Library and Information Science, Bobinski looked at the academic catalogs of 21 doctoral programs and analyzed his program requirements and course listings. ${ }^{[17]}$ Most recently, close to a million academic course, syllabi are now available for analysis through the Open Syllabus Project, the Syllabus Explorer (Open Syllabus Project). ${ }^{[18]}$ Initial metric analysis of this content has been to identify the articles and books most often assigned in various fields. ${ }^{[19]}$ Presumably, however, this resource can be mined to analyze subject content in academic courses and eventually might be used for longitudinal subject evolution studies such as the one contained in this article.

This work builds upon and contributes to the numerous metric studies that utilize large datasets to analyze topics or subjects in a domain. However, very few do so longitudinally (diachronically) over large periods of time using large datasets (Sugimoto et al., 2011, p. 186 $6^{[20]}$ asserting that most topic studies of the field of library and information science are "synchronic, rather than diachronic"). Harter and Hooten used bibliographic data to study 391 articles in three different time slices of the Journal of the American Society for Information Science from 1972 to 1990.[21] Sugimoto and McCain used tri-occurrence bibliographic analysis to map three time slices of information retrieval research from 1980 to 2004 (2010). ${ }^{[2]}$ Larivière et al. used bibliographic data to analyze 110 years of the field of library and information science and identified major shifts occurring in 1960 and 1990. ${ }^{[23]}$ Other work includes Järvelin and Vakkari, 1990; Milojevic et al., 2011; and Sugimoto et al., 2009.[24-26]

In addition to works that rely on existing metadata, there are longitudinal studies of domains that use algorithmic techniques to identify topics and then analyze the changes in frequency over time of those same topics. Smeaton et al. used information retrieval and clustering techniques to evaluate 25 years of SIGIR conference papers. ${ }^{[27]}$ Sugimoto et al. used latent Dirichlet allocation (LDA) to identify the topics of 3121 dissertations in the field of library and information science from 1930 to 2009 and noted changes over time. ${ }^{[20]}$ Song et al. used algorithmic techniques to cluster and analyze the evolution of topics in thirty-three bioinformatics conferences from 2000 to 2011, divided into four distinct time periods. ${ }^{[28]}$ Yan used LDA to analyze topics in over 50,000 publications in library and information science from 1955 to 2013. ${ }^{[29]}$ In addition, there have also been numerous visualization studies of domains that necessarily rely on metric analysis 
for input. Several of these are related to academic disciplines and courses. ${ }^{[30-32]}$

Furthermore, there have also been studies or claims that use the AALS course-subjects. Garvin used the AALS "List of Teachers by Subject" data to bolster his assertion that commercial law is "a dying field, and one with few signs of revival" (2007, p. 403). ${ }^{[33]}$ Garvin compared the number of commercial law professors with those in criminal law ("a stable field") and intellectual property ("a booming field") over a 40-year timespan (1965-1966 to 2005-2006). Commercial law saw a marked decline relative to those two other fields. Garvin also lamented the comparative aging of commercial law noting that "[y]oung scholars tend to be more productive than their seniors" and "[a]n aging field will tend to produce less scholarship and thus figure less in the minds of prospective law teachers." [33] Allen used the counts of faculty members teaching environmental law, law and medicine, and legal process to show that survey data reporting the number of law schools conducting jurimetrics ("the scientific investigation of legal problems") might be low (1975). ${ }^{[34]}$ Laycock used AALS subjects data to help tell the story about how the course remedies evolved (2008). ${ }^{[3]}$ In addition, Stadler made assertions about which legal subjects were waning in interest and which were on the rise (2006). ${ }^{[36]}$ Stadler hand coded 58 years of the Harvard Law Review (1946-2003) by correlating article content with law school course-subjects. She also coded if the article was written by a student (usually called a "note" or "comment") or by a nonstudent law professor or other legal professional. Using normalized values and a metric that captured the incidence of the number of student-written articles on a particular topic exceeding nonstudent-written articles, Stadler made judgments as to which subjects were popular and which were not. She couched her recommendations in the language of stock market analysis by making her recommendations for lawyers wishing to become law professors in terms of strong buys, weak buys, weak sells, and strong sells.

\section{Data and Methods}

This work was conducted pursuant to a grant from the Law School Admissions Council - The Production, Content and Consumption of Legal Scholarship: A Longitudinal Analysis. As a small part of the analysis, a student worker keyed into a database all course-subjects, together with their "includes statements" and "see also references," from each list of "Teachers by Subject" from 1931-1932 to 2011-2012. This resulted in 45 unique permutations of the law school course-subject canon over this period (in some years, there were no changes. Also, for some years, there were no lists of "Teachers by Subject" in the AALS annual directories). Student workers also inputted into a relational database which faculty members taught which course-subjects for the academic years (1) 1931-1932 and (2) 1972-1973. Since the beginning of the work on the grant, the AALS annual directories were scanned and made available as PDF's on the subscription legal database platform, Hein Online. The author used optical character recognition of these scanned images to harvest the data for 2010-2011. These later efforts indicate that all of the data could have been gathered algorithmically rather than by hand.

\section{Tracking Course-Subjects and Course-Subject Groupings over Time}

The author was able to glean how the course-subjects changed over time. This included when course-subjects either merged or diverged from a common parent. This work was assisted by the scope notes ("includes statements") that frequently accompanied a course-subject. For instance, "International Transactions includes Common Market, Foreign Patents, International Policies, International Taxation, and Regional Organizations." [37] Furthermore, the author was aided by cross-references and "see also" statements contained in some of the course-subjects: "Suretyship (See also Securities)" "[38] and "Financial Institutions (Cross-referenced under Regulated Industries)." [39] In addition, the timing of the appearance and disappearance of specific course-subjects was also used to determine which course-subjects continued others after a name change. In some instances, these decisions were assisted by looking at the continuity of named individuals from one course-subject grouping to another. Appendix 1 shows how the course-subjects are nested and evolved for years 1931-1932, 1972-1973, and 2010-2011. Schematic charts created with Microsoft Visio were used to visualize the mergence and divergence of two particularly troublesome groupings of course-subjects, Estate Planning, and Civil Procedure [Figures 1 and 2]. Most importantly, knowing how course-subjects relate to each other over time allows for meaningful metric comparisons across the eighty years of the dataset.

\section{Deduplication}

Unfortunately, there were widespread redundancies in the list of teachers by subjects that impacted the count information and had to be deduplicated by hand. Teachers were frequently listed several times under the same time bin (1-5 years, 6-10 years, and over 10 years) and 

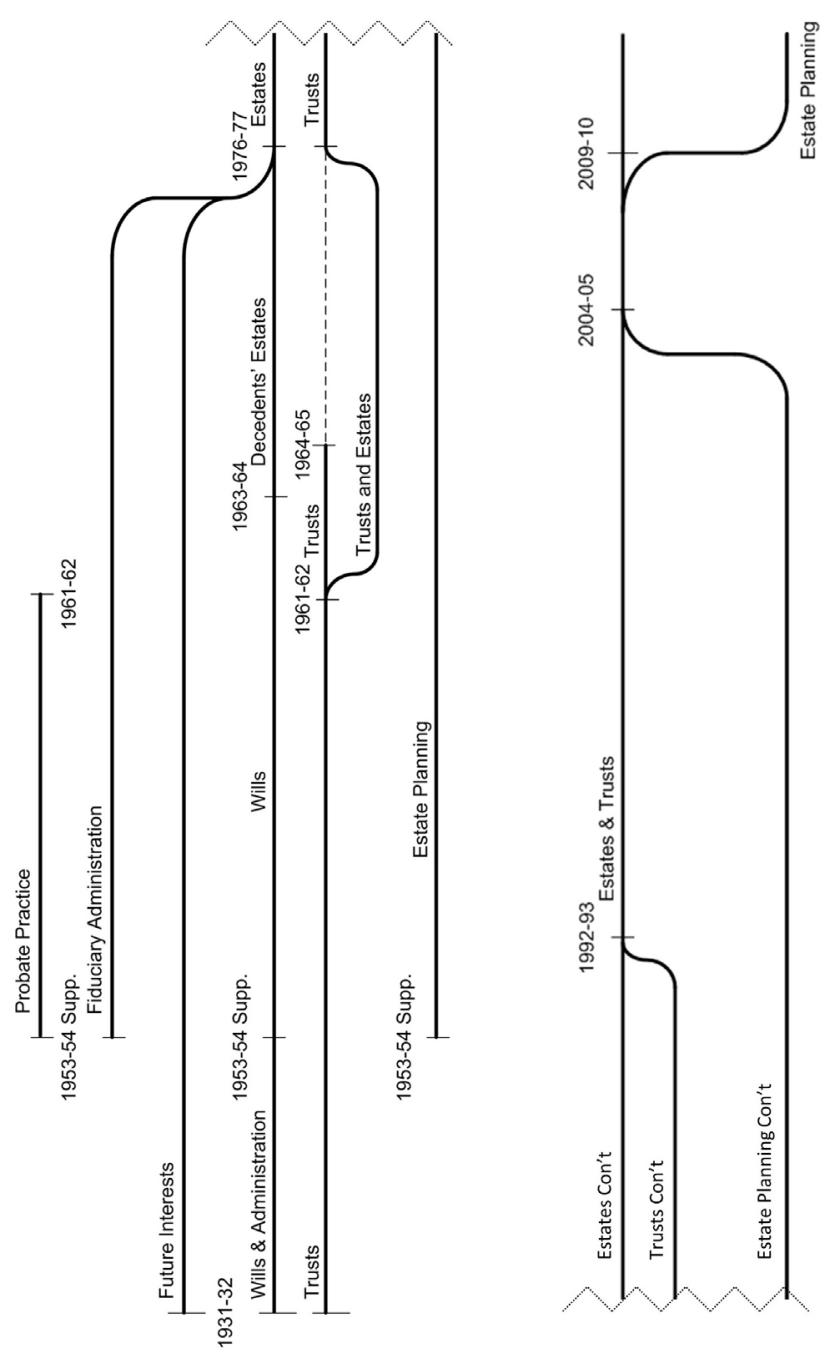

Figure 1: Mergence and divergence of estate planning coursesubjects

frequently in more than one-time bin. For the academic year 2010-11, there was a duplication rate of $8.3 \%$. Worse, some course-subjects had a much higher duplication rate. The highest was $26 \%$ for the course-subject, Intellectual Property. The duplicates were removed so that a faculty member appeared only once under each course-subject and in the highest time bin in which his or her name appears. The clean totals are shown in Table 2.

\section{RESULTS AND DISCUSSION}

Figures 1 and 2 reveal an interesting story of the evolution of the legal course-subject canon. Judging by the number of course-subjects in the canon, early law school education in the United States was much more concerned about the means to hold and convey assets (estate planning)

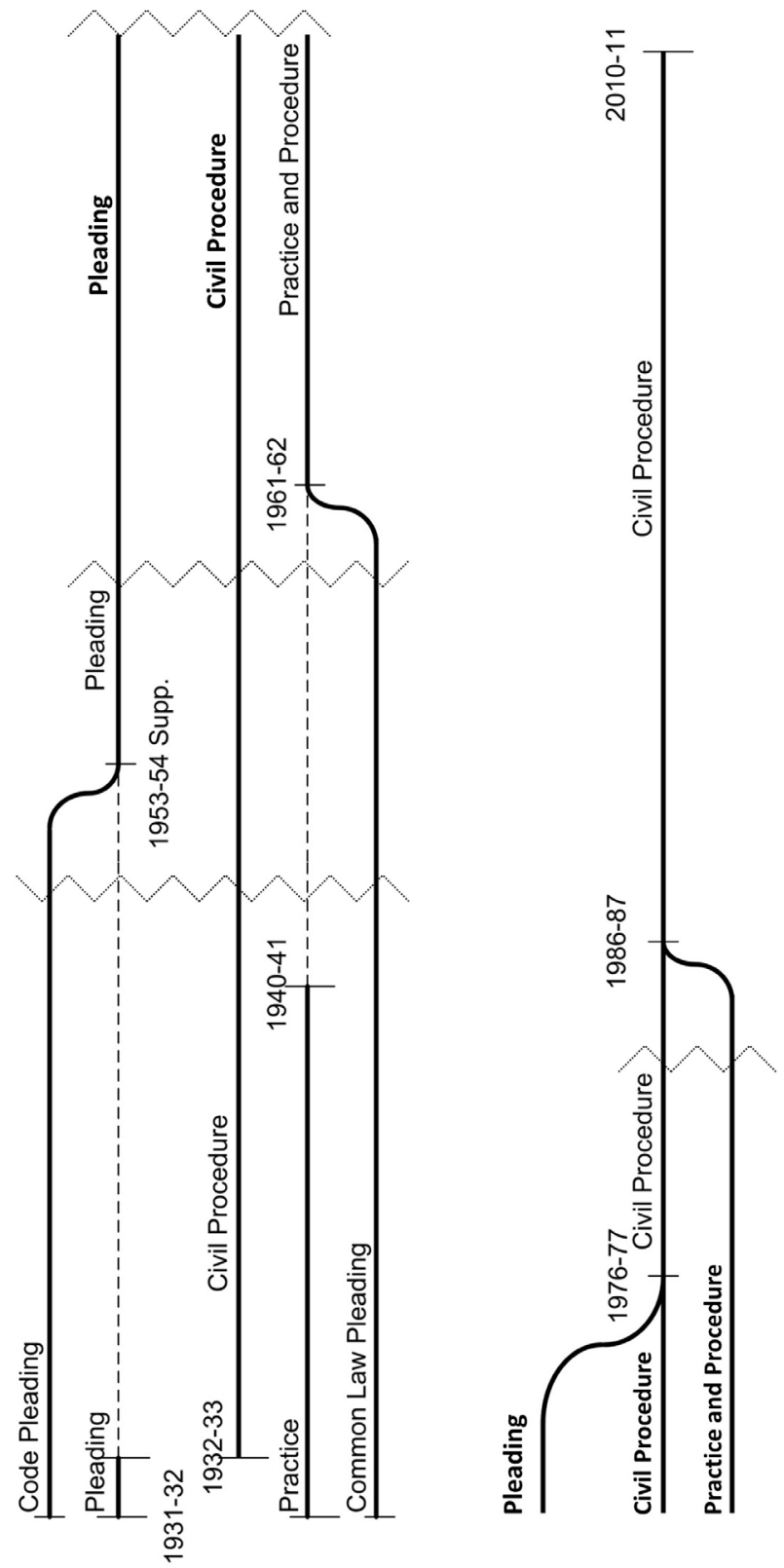

Figure 2: Mergence and divergence of procedural coursesubjects

than it is today. Similarly, early law school education involved many more and presumably more complex forms of pleading (the procedural rules and language used in the process of filing and advancing lawsuits) than used today. However, most importantly, knowing how course-subjects relate to each other over time allows for meaningful metric comparisons across the eighty years of the dataset.

\section{Most Gains in Percentage of the Overall Canon}

The dataset allows for an evaluation of the changes in percentage of the overall course-subject canon from 
1931-1932 to 2010-2011. This is true for either individual course-subjects or groupings of course-subjects. A ranking of the five greatest increases in the overall percentages is informative as to changes in the allocation of teaching resources in the American law schools during the 80 years of the dataset [Table 3]. The greatest percentage increase is in faculty teaching courses related to International Law. This is most likely due to the increase in globalization that has occurred in the interim and the rise of the Immigration and Human Rights as areas of concern in law school education. Constitutional Law is also much more prominent in 2010-2011 than it was in 1931-1932. This is most likely attributable to the rise in individual constitutional rights in the United States that has occurred over this same period. Legal Research and Writing has become a much more established part of the law school curriculum. In the past, some schools did not have legal research and writing faculty. Instead, third-year students taught the first year students these skills. The various criminal and tax course-subjects have also increased as to their overall percentage of how many faculty are teaching them.

Table 2: Relevant counts for thee academic years

\begin{tabular}{lccc}
\hline $\begin{array}{l}\text { Academic } \\
\text { year }\end{array}$ & $\begin{array}{c}\text { Number } \\
\text { of course- } \\
\text { subjects }\end{array}$ & $\begin{array}{c}\text { Number of faculty/ } \\
\text { course-subject } \\
\text { affiliations }\end{array}$ & $\begin{array}{c}\text { Number of course- } \\
\text { subject co-occurrences } \\
\text { (same faculty member } \\
\text { teaching two different } \\
\text { course-subjects) }\end{array}$ \\
\hline $1931-1932$ & 58 & 2674 & 5869 \\
$1972-1973$ & 86 & 19,025 & 44,364 \\
$2010-2011$ & 104 & 36,216 & 61,856 \\
\hline
\end{tabular}

\section{Most Losses in Percentage of Overall Canon}

Because percentages of the overall total are being evaluated, the gains discussed above must come at the expense of some course-subjects or course-subject groupings. A ranking of the five greatest decreases in the overall percentage of course-subjects taught is informative as to changes in the allocation of teaching resources in the American law schools from 1931-1932 to 2010-2011 [Table 4]. In the past, the American law schools were far more concerned about how one inherits property (estate planning). This topic has greatly diminished in importance in terms of the number of faculty members who at present teach it. At least one scholar has noted that commercial law was "a dying field and one with few signs of revival." [33] This is empirically supported by the metric analysis. Contemporary law schools, to teach new course-subjects such as Environmental Law, Sports Law, National Security Law, and Entertainment Law, must necessarily diminish the amount of resources devoted to teaching other parts of the canon that previously enjoyed a high percentage of the amount of teachers teaching particular course-subjects. This includes business organization courses (ranked $3^{\text {rd }}$ in overall losses). Similarly, equity and property have also diminished in terms of the overall percentage of what faculty members are teaching.

\section{Average Length Courses Have Been Taught}

Metric analysis may also be applied to the length of time faculty members have been teaching a particular coursesubject. This is made possible because the AALS directories

Table 3: Most gains in percentage of overall canon 1931-1932 to 2010-2011

\begin{tabular}{|c|c|c|c|c|c|c|c|}
\hline $\begin{array}{l}\text { Course-subjects } \\
1931-1932\end{array}$ & $\begin{array}{l}\text { Total } \\
\text { faculty }\end{array}$ & $\begin{array}{l}\text { Percentage of } \\
\text { total (total }=1.00 \text { ) }\end{array}$ & Course-subjects 2010-2011 & $\begin{array}{l}\text { Total } \\
\text { faculty }\end{array}$ & $\begin{array}{l}\text { Percentage of } \\
\text { total (total=1.00) }\end{array}$ & $\begin{array}{c}\text { Change in } \\
\text { percentage of } \\
\text { total (total=1.00) }\end{array}$ & Rank \\
\hline International law & 32 & 0.012 & $\begin{array}{l}\text { International business transactions } \\
\text { Immigration law } \\
\text { Human rights } \\
\text { International law } \\
\text { International organizations }\end{array}$ & 2088 & 0.058 & 0.046 & 1 \\
\hline Constitutional law & 89 & 0.033 & $\begin{array}{l}\text { Constitutional law } \\
\text { Civil rights } \\
\text { Employment discrimination }\end{array}$ & 2617 & 0.072 & 0.039 & 2 \\
\hline $\begin{array}{l}\text { Legal bibliography } \\
\text { and research }\end{array}$ & 45 & 0.017 & $\begin{array}{l}\text { Legal drafting; and legal research } \\
\text { and writing }\end{array}$ & 1744 & 0.048 & 0.031 & 3 \\
\hline $\begin{array}{l}\text { Criminal law } \\
\text { administration } \\
\text { Criminal law and } \\
\text { procedure }\end{array}$ & 111 & 0.042 & $\begin{array}{l}\text { Criminal justice } \\
\text { Criminal law } \\
\text { Criminal procedure } \\
\text { Juvenile law }\end{array}$ & 2558 & 0.071 & 0.029 & 4 \\
\hline Taxation & 36 & 0.013 & $\begin{array}{l}\text { Taxation, corporate } \\
\text { Taxation, state and local } \\
\text { Estate and gift tax } \\
\text { Taxation federal } \\
\text { Tax policy }\end{array}$ & 1149 & 0.032 & 0.019 & 5 \\
\hline
\end{tabular}


bin the faculty teaching the various course-subjects by the amount of years they have been teaching (1) 1-5 years, (2) 6-10 years, and (3) over 10 years. This allows scientometricians to know which courses are comparatively aged and not attracting new faculty. This may be accomplished by averaging the length of time one has been teaching a subject based on the following formula: $([1 \times$ amount in category 1 [teaching $1-5$ years] $)+(2 \times$ amount in category 2 [teaching 6-10 years] $)+(3 \times$ amount in category 3 [teaching over 10 years]))/overall amount of faculty teaching that particular course-subject. Table 5 displays the five most aged course-subjects for each of the time periods. Each of these course-subjects would most likely trigger a similar admonition that Garvin applied to Commercial Law: "[y]oung scholars tend to be more productive than their seniors" and "[a]n aging field will tend to produce less scholarship and thus figure less in the minds of prospective law teachers." ${ }^{[33]}$ Similarly, Stadler would likely classify each of these course-subjects as "strong sells." [36]

Table 6 displays the five youngest course-subjects for each of the time periods. For years 1972-1973 and 2010-2011, these course-subjects are most recently introduced and have not allowed faculty members to accrue many years of teaching experience in those particular course-subjects.
Included in Table 6 is a parenthetical which is the academic year the course-subject was first added to the canon of the list of law teachers by subject (the parentheticals are not included for the year 1931-1932 which is the year that the controlled course-subject taxonomy was first used). One noticeable exception to the trend of most of the "youngest" course-subjects being relatively new is Military Law. Introduced in the academic year 1941-1942 at the onset of the combat involvement of the United States in World War II, Military Law was subsequently refreshed with new teachers in the years preceding 20102011. Presumably, this is a result of the military endeavors of the United States following the terrorist attack of September 11, 2001, and a resultant increase in interest in Military Law at law schools in the United States.

The dataset used in this research is unique and is not commonplace in academia. However, metric insights such as the ones contained in this paper might inspire more learned societies to keep directory information similar to the AALS. Furthermore, it is now possible to scrape such content off of institutional websites. As the studies in the related work section show, scholars use the insights gained from these kinds of studies. This work exemplifies one way that such studies may be accomplished.

Table 4: Most losses in percentage of overall canon 1931-1932 to 2010-2011

\begin{tabular}{|c|c|c|c|c|c|c|c|}
\hline $\begin{array}{l}\text { Course-subjects } \\
1931-1932\end{array}$ & $\begin{array}{l}\text { Total } \\
\text { faculty }\end{array}$ & $\begin{array}{l}\text { Percentage of } \\
\text { total (total }=1.00 \text { ) }\end{array}$ & $\begin{array}{c}\text { Course-subjects } \\
2010-2011\end{array}$ & $\begin{array}{l}\text { Total } \\
\text { faculty }\end{array}$ & $\begin{array}{l}\text { Percentage of } \\
\text { total (total }=1.00 \text { ) }\end{array}$ & $\begin{array}{c}\text { Change in } \\
\text { percentage of } \\
\text { total (total=1.00) }\end{array}$ & Rank \\
\hline $\begin{array}{l}\text { Wills and administration } \\
\text { Future interests } \\
\text { Trusts }\end{array}$ & 210 & 0.079 & $\begin{array}{l}\text { Estate planning } \\
\text { Estates and trusts }\end{array}$ & 633 & 0.017 & -0.062 & 1 \\
\hline $\begin{array}{l}\text { Sales } \\
\text { Credit transactions } \\
\text { Suretyship } \\
\text { Mortgages }\end{array}$ & 213 & 0.080 & $\begin{array}{l}\text { Commercial law } \\
\text { Real estate } \\
\text { transactions }\end{array}$ & 884 & 0.024 & -0.056 & 2 \\
\hline $\begin{array}{l}\text { Agency } \\
\text { Partnership } \\
\text { Business organization } \\
\text { Private corporations } \\
\text { Corporation finance }\end{array}$ & 249 & 0.093 & $\begin{array}{c}\text { Agency and } \\
\text { partnership } \\
\text { Business associations } \\
\text { Corporate finance }\end{array}$ & 1441 & 0.040 & -0.053 & 3 \\
\hline $\begin{array}{l}\text { Equity } \\
\text { Equity pleading and practice }\end{array}$ & 124 & 0.046 & Equity & 51 & 0.001 & -0.045 & 4 \\
\hline $\begin{array}{l}\text { Personal property } \\
\text { Real property }\end{array}$ & 199 & 0.074 & Property & 1123 & 0.031 & -0.043 & 5 \\
\hline
\end{tabular}

Table 5: Five most aged course-subjects

\begin{tabular}{|c|c|c|c|c|c|}
\hline $\begin{array}{l}1931-1932 \\
\text { course-subjects }\end{array}$ & $\begin{array}{l}\text { Average length of } \\
\text { time being taught }\end{array}$ & $\begin{array}{l}\text { 1972-1973 course- } \\
\text { subjects }\end{array}$ & $\begin{array}{l}\text { Average length of } \\
\text { time being taught }\end{array}$ & 2010-2011 course-subjects & $\begin{array}{l}\text { Average length of } \\
\text { time being taught }\end{array}$ \\
\hline Mining law & 2.571 & Future Interests & 2.042 & Taxation, federal & 2.325 \\
\hline Water rights & 2.429 & Pleading & 1.900 & Payment systems & 2.274 \\
\hline Patent law & 2.000 & Librarian & 1.891 & Admiralty & 2.271 \\
\hline Pleading & 2.000 & Oil and gas & 1.862 & Estate and gift tax & 2.228 \\
\hline Constitutional law & 1.876 & Practice and procedure & 1.737 & Creditors' and debtors' rights & 2.206 \\
\hline
\end{tabular}


Table 6: Youngest course-subject

\begin{tabular}{lclclc}
\hline $\begin{array}{l}\text { 1931-1932 course- } \\
\text { subjects }\end{array}$ & $\begin{array}{c}\text { Average } \\
\text { length of time } \\
\text { being taught }\end{array}$ & 1972-1973 course-subjects & $\begin{array}{c}\text { Average } \\
\text { length of time } \\
\text { being taught }\end{array}$ & $\begin{array}{c}\text { Average } \\
\text { length of time } \\
\text { being taught }\end{array}$ \\
\hline Air law & 1.00 & Women and the law (1972-1973) & 1.000 & Forensic medicine (2005-2006) \\
Business organization & 1.00 & Environmental law (1970-1971) & 1.022 & National security law (2009-2010) & 1.000 \\
Corporation finance & 1.00 & Clinical teaching (1971-1972) & 1.026 & Judicial administration (1938-1939) & 1.300 \\
Office practice & 1.091 & Law and poverty (1966-1967) & 1.046 & Military law (1941-1942) & 1.361 \\
Industrial relations & 1.167 & $\begin{array}{l}\text { Education, legal problems of } \\
\text { (1972-1973) }\end{array}$ & 1.050 & Energy law (2005-2006) & \\
\hline
\end{tabular}

\section{CONCLUSIONS AND FUTURE WORK}

This work is typical of the meta-pursuit which is information science. In other words, it "conduct[s] research and develop $[\mathrm{s}]$ theory around the documentary products of other disciplines and activities" and uses the "recorded information" that is a product of the "human agency" of a particular field. ${ }^{[40]}$ In this case, the recorded information is the annual directories of law teachers of the AALS. Metric analysis and a rich culture of data reporting in the legal academy of the United States combine to tell an informative empirical history of legal education. The data reveal which courses are "hot" and which courses are "cold." As with the topic analysis based on articles published in the Harvard Law Review, but on a far more limited scale, ${ }^{[36]}$ aspiring faculty may wish to consult this article to inform their decisions as to what to teach upon entering the legal academy.

As noted in the literature review, there have been very few empirical studies that systematically analyze the evolution of a field. This work contributes to scientometrics by identifying a rich data source for metric analysis of the domain of law in the United States. Furthermore, it exemplifies how the "includes" statements and "see also" notes of a controlled vocabulary or thesaurus may be used to trace the creation, discontinuation, mergence, and divergence of topics to make accurate, large-scale comparisons over time. Admittedly, the dataset used herein is relatively novel. Few disciplines systematically record which faculty members teach which courses year after year. However, a similar analysis can be applied to any literature that has been indexed with assigned topics over time from a thesaurus. For instance, the author would like to do a similar longitudinal (diachronic) study analyzing changes in subject frequency in legal periodicals as contained in the Index to Legal Periodicals and Books. In future and in addition to updating the metric analysis contained in this article, the author would like to analyze the differences in faculty allocations to the various course-subjects at schools from both highest tier (top 25\%) and lowest tier (bottom 25\%) of law schools according to the US News and World Reports rankings of law schools. Differences are expected because the most prestigious schools have larger budgets and a greater ability to allow their faculty to specialize and teach course-subjects of their choice. Finally, the author would like to publish mobility studies of law faculty as they migrate between schools and the resultant network of law schools the frequently exchange faculty.

\section{Financial Support and Sponsorship}

Thank you to the Law School Admissions Council (LSAC) whose generous grant of $\$ 159,511$ (The Production, Content, and Consumption of Legal Scholarship: A Longitudinal Analysis) helped to make this research possible.

\section{Conflicts of Interest}

There are no conflicts of interest.

\section{REFERENCES}

1. AALS. The Association of American Law Schools; 2015. Available from: http://www.aals.org/. [Last retrieved on 2015 Aug 04].

2. AALS. Directory of Teachers in Member Schools: 1931. Saint Paul, Minnesota: West Publishing Co.; 1931.

3. AALS. The AALS Directory of Law Teachers 2011-2012. Washington, D.C.: AALS; 2011.

4. Hook PA. Using course-subject co-occurrence (CSCO) to reveal the structure of an academic discipline: A framework to evaluate different inputs of a domain map. J Assoc Inf Sci Technol. [In Press].

5. AALS. Directory of Teachers in Member Schools: 1930. Saint Paul, Minnesota: West Publishing Co.; 1930.

6. AALS. Directory of Teachers in Member Schools: 1940-1941. Saint Paul, Minnesota: West Publishing Co.; 1940.

7. AALS. Directory of Teachers in Member Schools: 1950-1951. Saint Paul, Minnesota: West Publishing Co.; 1950.

8. AALS. Directory of Law Teachers in American Bar Association Approved Law Schools: 1961. Saint Paul, Minnesota: West Publishing Co.; 1960.

9. AALS. Directory of Law Teachers: 1970. Saint Paul, Minnesota: West Publishing Co.; 1970.

10. AALS. Directory of Law Teachers: $1980-81$. Saint Paul, Minnesota: West Publishing Co.; 1981.

11. AALS. The AALS Directory of Law Teachers: 1989-90. Saint Paul, Minnesota: West Publishing Company; 1989. 
12. AALS. The Association of American Law Schools; 2013. Available from: http://www.aals.org/. [Last retrieved on 2013 Sep 09].

13. ABA, LSAC. ABA-LSAC Official Guide to ABA-Approved Law Schools. $2011^{\text {th }}$ ed. Newtown, Pennsylvania: LSAC; 2010.

14. Cronin B, Sugimoto CR, editors. Scholarly Metrics Under the Microscope: From Citation Analysis to Academic Auditing. Medford, New Jersey: Information Today, Inc.; 2015.

15. Milojević S, Leydesdorff L. Information metrics (iMetrics): A research specialty with a socio-cognitive identity? Scientometrics. 2013;95:141-57.

16. Perlman B, McCann LI. The most frequently listed courses in the undergraduate psychology curriculum. Teach Psychol. 1999;26:177-82.

17. Bobinski GS. Doctoral programs in library and information science in the United States and Canada. Libr Trends. 1986;34:697-714.

18. Open Syllabus Project. Open Syllabus Project: Opening the Curricular Black Box. Available from: http://www.opensyllabus project.org/. [Last retrieved on 2016 Jan 27].

19. Karaganis J, McClure D. What a Million Syllabuses Can Teach Us. New York Times; 22 January, 2016. Available from: http:// www.nytimes.com/2016/01/24/opinion/sunday/what-a-millionsyllabuses-can-teach-us.html.

20. Sugimoto CR, Li D, Russell TG, Finlay SC, Ding Y. Shifting sands of disciplinary development: Analyzing North American library and information science dissertations using latent Dirichlet allocation. J Am Soc Inf Sci Technol. 2011;62:185-2011.

21. Harter SP, Hooten PA. Information science and scientists: JASIS, 1972-1990. J Am Soc Inf Sci. 1992;43:583-93.

22. Sugimoto $\mathrm{CR}$, McCain KW. Visualizing changes over time: A history of information retrieval through the lens of descriptor tri-occurrence mapping. J Inf Sci. 2010;36:481-93.

23. Larivière $V$, Sugimoto $C R$, Cronin $B$. A bibliometric chronicling of library and information science's first hundred years. J Am Soc Inf Sci Technol. 2012;63:997-1016.

24. Järvelin K, Vakkari P. Content analysis of research articles in library and information science. Libr Inf Sci Res. 1990;12:395421.
25. Milojevic S, Sugimoto CR, Yan E, Ding Y. The cognitive structure of library and information science: Analysis of article title words. J Am Soc Inf Sci Technol. 2011;62:1933-53.

26. Sugimoto CR, Russell TG, Grant S. Library and information science doctoral education: The landscape from 1930-2007. J Educ Libr Inf Sci. 2009;50:190-202.

27. Smeaton AF, Keogh G, Gurrin C, McDonald K, Sødring T. Analysis of papers from twenty-five years of SIGIR conferences: What have we been doing for the last quarter of a century? ACM SIGIR Forum. 2003;37:49-53.

28. Song M, Heo GE, Kim SY. Analyzing topic evolution in bioinformatics: Investigation of dynamics of the field with conference data in DBLP. Scientometrics. 2014;101:397-428.

29. Yan E. Research dynamics, impact, and dissemination: A topiclevel analysis. J Assoc Inf Sci Technol. 2015;66:2357-72.

30. Biglan A. Characteristics of subject matter in different academic areas. J Appl Psychol. 1973;57:195-203.

31. White HD, Calhoun K. Mapping a curriculum by computer. J Am Soc Inf Sci. 1984;35:82-9.

32. White HD, Nolt $C$. Remapping a curriculum by computer: Change over time. J Educ Libr Inf Sci. 1987;28:123-35.

33. Garvin LT. The strange death of academic commercial law. Ohio State Law J. 2007:68:403-33.

34. Allen LE. Preface. Jurimetrics J. 1975;72:72-3.

35. Laycock D. How remedies became a field: A history. Rev Litig. 2008;27:161-267.

36. Stadler SK. The bulls and bears of law teaching. Washington Lee Law Rev. 2006;63:25-77.

37. AALS. Directory of Law Teachers in American Bar Association Approved Law Schools: 1964. Saint Paul, Minnesota: West Publishing Co.; 1963.

38. AALS. Directory of Teachers in Member Schools: 1935. Saint Paul, Minnesota: West Publishing Co.; 1935.

39. AALS. The AALS Directory of Law Teachers: 2004-2005. Saint Paul, Minnesota: Thomson West; 2004.

40. Bates MJ. The invisible substrate of information science. J Am Soc Inf Sci 1999;50:1043-50. 


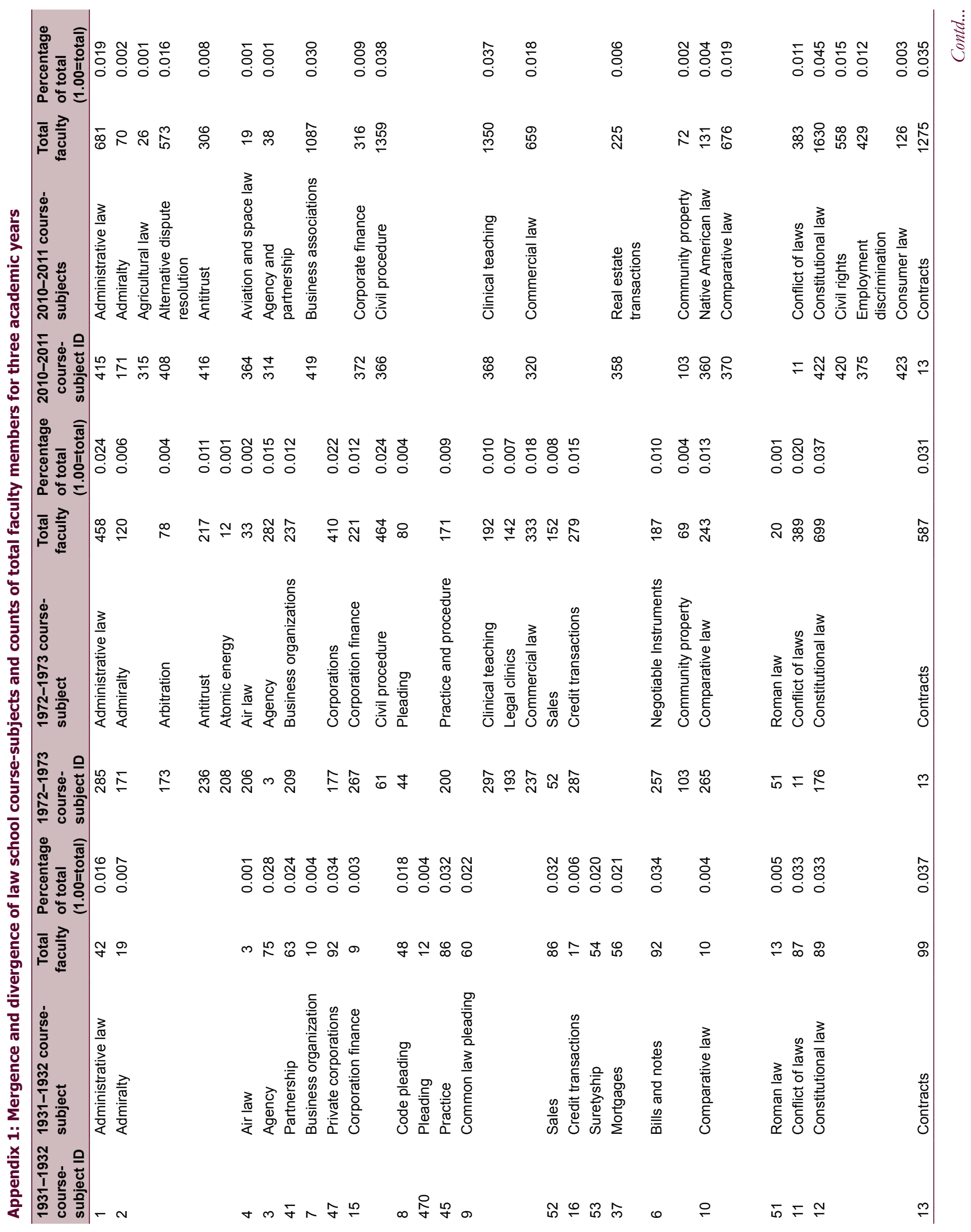


Peter A. Hook: Change in teaching frequency

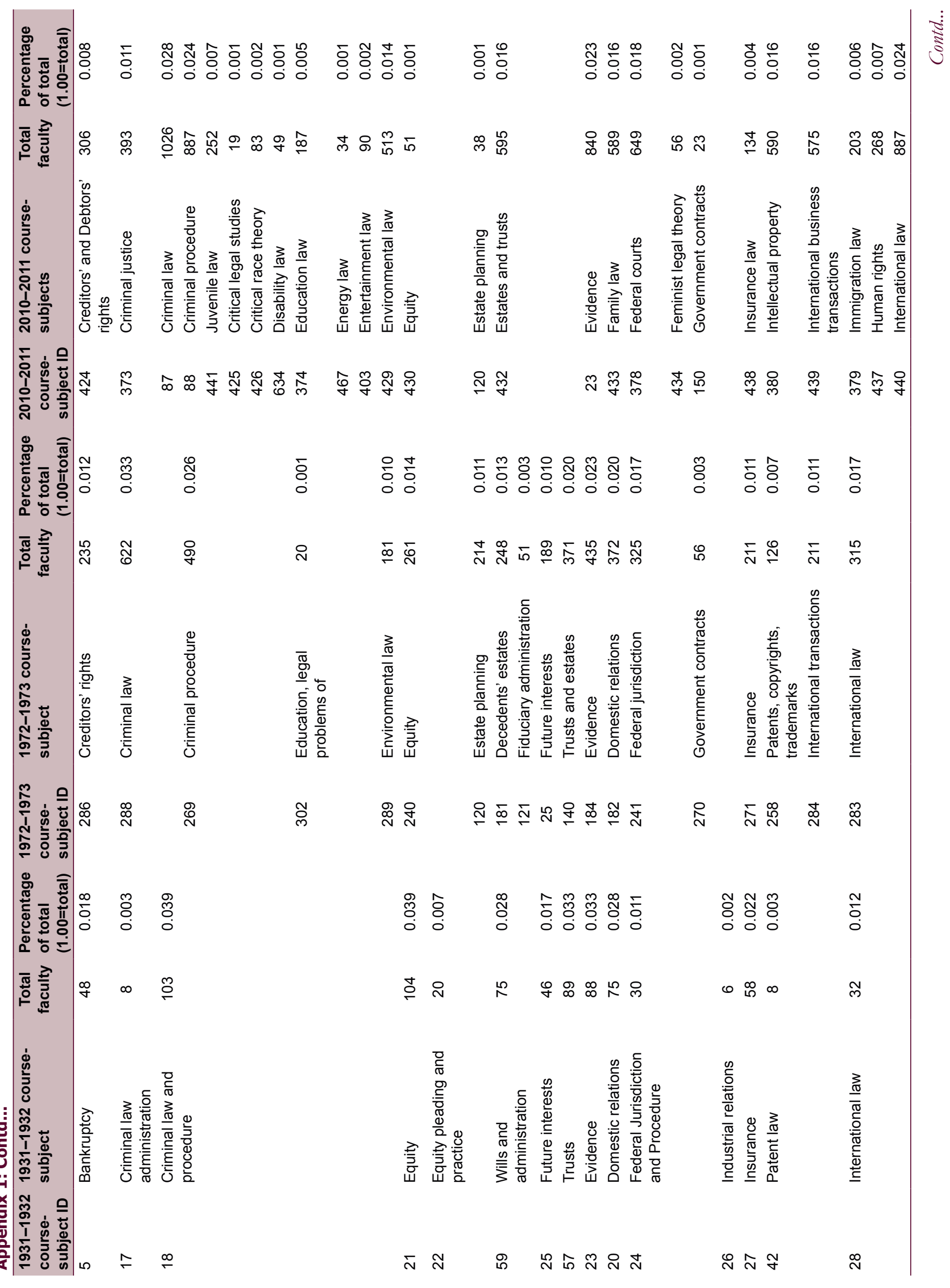




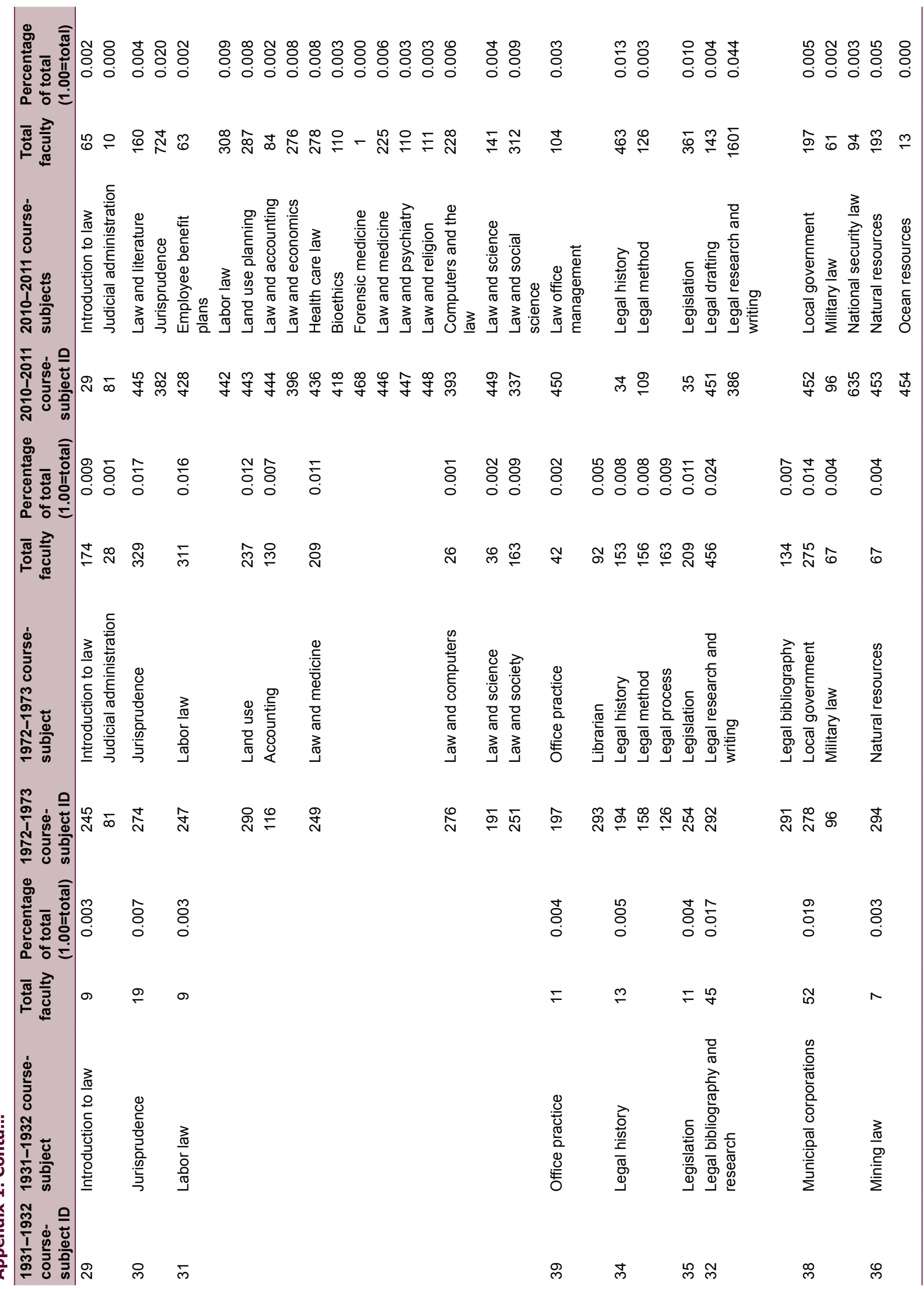




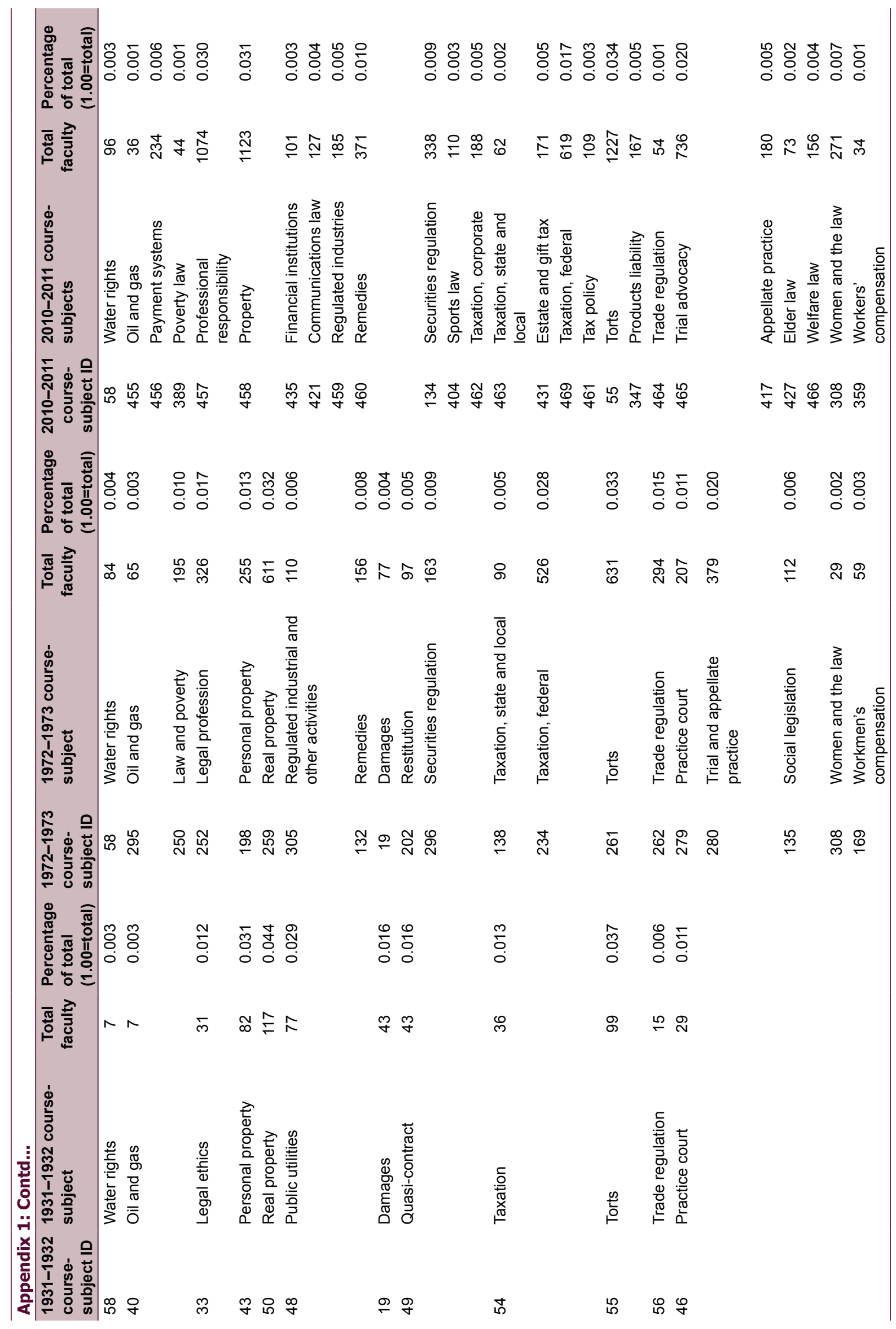

